University of Nebraska - Lincoln

DigitalCommons@University of Nebraska - Lincoln

Papers in Natural Resources

Natural Resources, School of

2014

Relationship between fraction of radiation absorbed by photosynthesizing maize and soybean canopies and NDVI from remotely sensed data taken at close range and from MODIS $250 \mathrm{~m}$ resolution data

\author{
Anatoly A. Gitelson \\ University of Nebraska - Lincoln, agitelson2@unl.edu \\ Yi Peng \\ University of Nebraska-Lincoln, ypeng2@unl.edu \\ Karl Fred Huemmrich \\ NASA Goddard Space Flight Center
}

Follow this and additional works at: http://digitalcommons.unl.edu/natrespapers

Gitelson, Anatoly A.; Peng, Yi; and Huemmrich, Karl Fred, "Relationship between fraction of radiation absorbed by photosynthesizing maize and soybean canopies and NDVI from remotely sensed data taken at close range and from MODIS $250 \mathrm{~m}$ resolution data" (2014). Papers in Natural Resources. 501.

http://digitalcommons.unl.edu/natrespapers/501

This Article is brought to you for free and open access by the Natural Resources, School of at DigitalCommons@University of Nebraska - Lincoln. It has been accepted for inclusion in Papers in Natural Resources by an authorized administrator of DigitalCommons@University of Nebraska - Lincoln. 


\title{
Relationship between fraction of radiation absorbed by photosynthesizing maize and soybean canopies and NDVI from remotely sensed data taken at close range and from MODIS $250 \mathrm{~m}$ resolution data
}

\author{
Anatoly A. Gitelson ${ }^{\text {a,* }}$, Yi Peng ${ }^{\text {a }}$, Karl F. Huemmrich ${ }^{\text {b }}$ \\ a CALMIT, School of Natural Resources, University of NE-Lincoln, Lincoln, USA \\ b University of MD Baltimore County, Joint Center for Earth Systems Technology, NASA Goddard Space Flight Center, Greenbelt, USA
}

\section{A R T I C L E I N F O}

\section{Article history:}

Received 27 August 2013

Received in revised form 3 February 2014

Accepted 28 February 2014

Available online 27 March 2014

\section{Keywords:}

Absorbed photosynthetically active radiation

NDVI

Reflectance

\begin{abstract}
A B S T R A C T
The fraction of incident photosynthetically active radiation absorbed by the photosynthesizing tissue in a canopy (fAPAR) is a key variable in the assessment of vegetation productivity. It also plays tremendous role in accurate retrieval of light use efficiency, which is essential for assessing vegetation health status. The main goal of this work was to study in detail relationships of fAPAR absorbed by photosynthetically active vegetation ( fAPAR $_{\text {green }}$ ) and Normalized Difference Vegetation Index (NDVI) for two crops with contrasting leaf structures (C3 vs. C4) and canopy architectures, using close range ( $6 \mathrm{~m}$ above the canopy) radiometric data and daily MODIS data taken during eight growing seasons over three irrigated and rainfed maize and soybean sites. Our specific goal was to understand differences in $\mathrm{FAPAR}_{\text {green }} / \mathrm{NDVI}$ relationship when crop canopy was almost vertically homogeneous (with respect to leaf area and leaf chlorophyll content), as in vegetative stage, and vertically heterogeneous as in reproduction stage. Firstly, we established $\mathrm{AAPAR}_{\text {green }} / \mathrm{NDVI}$ relationships for NDVI, taken at close range, and

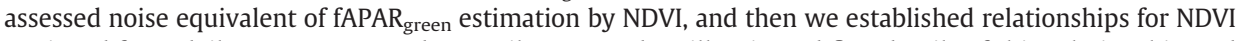
retrieved from daily MODIS $250 \mathrm{~m}$ data. Daily MODIS data illuminated fine details of this relationship and

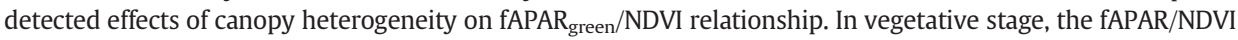
relationships for contrasting in leaf structures and canopy architectures crops were almost linear allowing accurate estimation of fAPAR green as it is below 0.7 . However, very different fAPAR green $_{\text {NDVI relationships in repro- }}$ ductive stages for both crops were observed, showing that canopy architecture and leaf structure greatly affect the relationship as leaf chlorophyll content changes and vertical distribution of chlorophyll content and green LAI inside the canopy becomes heterogeneous. We have found fine details of the fAPAR green $_{\text {NDVI relationships }}$ with two types of hysteresis that prevent the use of a single relationship for fAPAR green estimation by NDVI over the whole growing season and suggested mechanisms for each type of hysteresis that should be further studied using radiative transfer models.
\end{abstract}

(C) 2014 Elsevier Inc. All rights reserved.

\section{Introduction}

The fraction of incident photosynthetically active radiation (400$700 \mathrm{~nm}$ ) absorbed by the photosynthesizing tissue in a canopy (fAPAR) (Monteith, 1972) is a key variable in the assessment of vegetation productivity and yield estimates. An accurate estimation of fAPAR is an important detail in large scale productivity and carbon budget models (Prince, 1991). It plays tremendous role in accurate retrieval of light use efficiency, which is essential for assessing vegetation health status.

fAPAR can be determined from remote observations of surface spectral reflectance on the premise that surface structural and optical

\footnotetext{
* Corresponding author.

E-mail address: agitelson2@unl.edu (A.A. Gitelson).
}

properties are governed by ground cover/vegetation fraction and leaf area index - LAI (e.g., Myneni \& Williams, 1994; Tucker, 1979). There is substantial empirical evidence that fAPAR is related to top of the canopy spectral vegetation indices (VI), which are calculated based on mathematical combinations of ratios, differences and sums of spectral reflectance data (Asrar, Fuchs, Kanemasu, \& Hatfield, 1984; Daughtry, 1988; Daughtry, Gallo, \& Bauer, 1983; Gallo, Daughtry, \& Bauer, 1985; Hatfield, Asrar, \& Kanemasu, 1984 among others). This has also been demonstrated using radiative transfer models of varying degree of detail (Asrar, Myneni, \& Choudhury, 1992; Baret \& Guyot, 1991; Choudhury, 1987; Goward \& Huemmrich, 1992; Huemmrich, 1995; Myneni, Asrar, Tanre, \& Choudhury, 1992; Myneni \& Williams, 1994; Sellers, 1985 among others).

While this body of empirical evidence is impressive and radiative transfer model simulations of the fAPAR/NDVI relationship are quite close to each other, the predictions of fAPAR from in situ measured 
NDVI as well as from Moderate Resolution Imaging Spectroradiometer (MODIS)- and Advanced Very High Resolution Radiometer (AVHRR)retrieved NDVI are very different (e.g., Table 1 in Ruimy et al., 1994). Radiative transfer model predictions were quite close for different types of vegetation in California (Sims et al., 2006) while greatly overestimated AAPAR for three different vegetation types in Senegal (using in situ and MODIS-retrieved NDVI - Fensholt, Sandholt, \& Rasmussen, 2004) as well as for Kalahari Woodland in Africa (using MODIS-retrieved NDVI - Huemmrich, Privette, Mukelabai, Myneni, \& Knyazikhin, 2005). On another hand, they greatly underestimate fAPAR using in situ measured NDVI in wheat (Asrar et al., 1984) and deciduous forest (Nakaji, Ide, Oguma, Saigusa, \& Fujinuma, 2007). The slope of the relationship for AVHRR data presented by Ruimy et al., 1994 was very close to that predicted by radiative transfer models (around 1.25), however, the offset was 0.08-0.15 smaller than predicted by models. While nonlinear behavior of the relationship fAPAR/NDVI was predicted by radiative transfer modes, all empirical relationships published to date, demonstrated perfectly linear relations even for LAI as high as 7 (e.g. Daughtry, 1988). The exceptions are Gallo et al. (1985) and Viña and Gitelson (2005) studies showing essentially nonlinear relationship for corn (former) and for corn and soybean (latter) with significant decrease in sensitivity of NDVI to fAPAR exceeded 0.8 . Given the importance of fAPAR for ecosystem modeling, it is critical to understand and quantify the sources of variability in NDVI/fAPAR relationships.

In crops, usually the relationships of fAPAR vs. NDVI for green-up stage were presented. In few studies the relationships also for reproductive stage were established, however, total fAPAR, which includes fractions of PAR absorbed by both photosynthetic and non-photosynthetic components, was measured and analyzed in those relationships (Asrar et al., 1984; Gallo et al., 1985; Hatfield et al., 1984). To measure the radiation absorbed only by photosynthetic components following variation of vegetation greenness, fAPAR $_{\text {green }}$ was then defined as product of total fAPAR and ratio of green LAI to total LAI as suggested by Hall, Huemmrich, Goetz, Sellers, and Nickerson (1992). To the best of our knowledge, only one study - Sims et al. (2006) established relationship between fAPAR $_{\text {green }}$ and NDVI for several types of vegetation in California.

Few experimental sites studying fAPAR/NDVI relationships were found for natural vegetation in the literature (Bartlett, Whiting, \& Hartmann, 1990; Fensholt et al., 2004; Huemmrich et al., 2005; Nakaji et al., 2007; Peterson \& Running, 1989; Sims et al., 2006). While a linear relationship fAPAR vs. NDVI still applies, it is much different for these types of natural vegetation and also significantly different from that for crops. Thus, almost all previous publications on the subject show that the fAPAR/NDVI relationship varies significantly with the structure of the canopy and the background optical properties (e.g., Goward \& Huemmrich, 1992; Ruimy et al., 1994.

Huemmrich (2013) showed that the different leaf inclination angle distributions (LAD) affected the fAPAR and NDVI with similar relationships between FAPAR and LAI, but different relationships between NDVI and LAI for the different LAD types. These differences resulted in significantly different nonlinear relationships between NDVI and fAPAR for each LAD type. Huemmrich (2013) concluded that attempting to predict fAPAR from NDVI may result in errors of as much as $40 \%$, if one does not take into account the effects of canopy structure and latitude.

Thus, there are many important, but less understood, factors

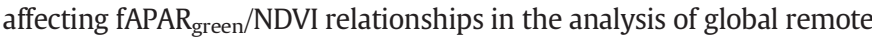
sensing observations. MODIS fAPAR product is derived either using a radiative transfer model inversion (main algorithm) or, in some conditions when main algorithm fails, using a NDVI relationship (backup algorithm) - Myneni et al. (2002). In several works it was shown that the MODIS fAPAR product overestimated fAPAR almost in the same way as NDVI (Fensholt et al., 2004; Huemmrich et al., 2005 among others). Thus, studying fAPAR $_{\text {green/NDVI relationship may bring more }}$ understanding of uncertainties of fAPAR green $_{\text {estimation by MODIS }}$

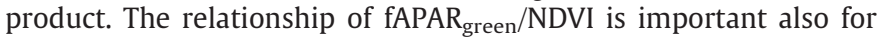
specific field studies requiring spatial resolution better than the MODIS product ( $1 \mathrm{~km}$ resolution) - 250 and $500 \mathrm{~m}$, as well as in the continued use of NDVI in phenology studies as the fAPAR/NDVI relationship connects the seasonal NDVI pattern with seasonal vegetation productivity. It is also essential to understand factors affecting fAPAR green/ NDVI relationship due to persistent use of NDVI as a proxy of fAPAR in estimating light use efficiency (e.g., Garbulsky, Penuelas, Gamon, Inoue, \& Filella, 2011; Sims et al., 2006; Wu, Niua, \& Gaoa, 2012). Even small errors in fAPAR $_{\text {green }}$ estimation using NDVI can bring 2-3 fold errors in light use efficiency assessment.

A lack of high temporal resolution in situ data and satellite data has

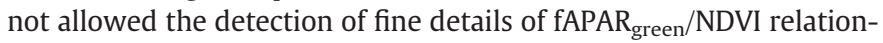
ships that can be observed with daily observations. This is especially the case for vegetation with variable leaf chlorophyll content and leaf area index (as crops, grasslands and deciduous forests) through the growing season. This is a key point because the most published radiative transfer simulations of fAPAR/NDVI relationships (with exception, to the best of our knowledge, Guillevic \& Gastellu-Etchegorry, 1999) have dealt with vertically homogeneous (with respect to LAD, leaf area and leaf chlorophyll content) canopies, which does not hold in many cases.

The main goal of this work was to study in detail fAPAR green $_{\text {NDVI }}$ relationships for two contrasting crops using in situ ( $6 \mathrm{~m}$ above the canopy) radiometric data and daily MODIS data taken during eight growing seasons over three maize and soybean FLUXNET sites including both irrigated and rainfed crops. Maize and soybean species have very different biochemical mechanisms for photosynthesis. Maize utilizes C4 carbon fixation, while soybean utilizes C3 carbon fixation. In addition, they have contrasting canopy architectures, with a spherical leaf inclination angle distribution in maize and a heliotropic distribution in soybeans. Our specific goal was to understand the differences in

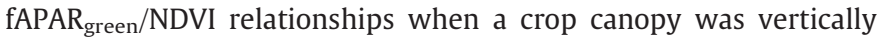
homogeneous (with respect to greenness/leaf chlorophyll content, leaf area and LAD), as in vegetative stage, and vertically heterogeneous as in reproduction stage when leaf chlorophyll content declines differently in leaf layers and vertical distribution of chlorophyll and green leaf area change drastically (Ciganda, Gitelson, \& Scheper, 2012; Ciganda, Gitelson, \& Schepers, 2008). Firstly, we established fAPAR green/NDVI relationships for NDVI, taken in situ, and assessed noise equivalent of fAPAR $_{\text {green }}$ estimation by NDVI, and then established relationships for NDVI retrieved from daily MODIS data. Daily MODIS data illuminated fine details of this relationship and detected effects of vertical canopy heterogeneity on AAPAR $_{\text {green/NDVI relationships. }}$

\section{Data and methods}

\subsection{Study area}

FLUXNET is a network coordinating regional and global analysis of observations from micrometeorological tower sites using eddy covariance methods to measure the exchange of carbon dioxide, water vapor and energy between terrestrial ecosystems and the atmosphere (http://fluxnet.orn.gov). Three FLUXNET sites were studied in our investigation, which are located at the University of Nebraska-Lincoln Agricultural Research and Development Center near Mead, Nebraska, USA. The three sites are all approximately 60 -ha fields within $1.6 \mathrm{~km}$ of each other. Site 1 (US-Ne1: $41^{\circ} 09^{\prime} 54.2^{\prime \prime} \mathrm{N}, 9^{\circ} 28^{\prime} 35.9^{\prime \prime} \mathrm{W}$ ) is planted in continuous maize and equipped with a center pivot irrigation system. Site 2 (US-Ne2: $41^{\circ} 09^{\prime} 53.5^{\prime \prime} \mathrm{N}, 96^{\circ} 28^{\prime} 12.3^{\prime \prime} \mathrm{W}$ ) and site 3 (US-Ne3: $41^{\circ} 10^{\prime} 46.8^{\prime \prime} \mathrm{N}, 96^{\circ} 28^{\prime} 22.7^{\prime \prime} \mathrm{W}$ ) are both planted in a maize-soybean rotation with maize planted in odd years and soybean planted in even years, but the former is irrigated in the same way as site 1 , while site 3 relies entirely on rainfall for moisture. Site descriptions are available at: http://fluxnet.ornl.gov/site/951; http://fluxnet.ornl.gov/site/952; 
http://fluxnet.ornl.gov/site/953. More information about the major crop management in those study sites was given in Suyker and Verma (2010).

\subsection{Destructive determination of leaf area index (LAI)}

To represent green LAI of entire site, within each of the three study sites, six small plot areas ( $20 \mathrm{~m} \times 20 \mathrm{~m}$ ) were selected using fuzzy-kmeans clustering (Minasny \& McBratney, 2003), which represented all major occurrences of soil and crop production zones within each field (Verma et al., 2005). LAI was estimated from destructive samples at 10-14 day intervals during the growing season from 2001 to 2008. On each sampling date, plants from a $1 \mathrm{~m}$ length of either of two rows within each plot were collected and the total number of plants recorded. Plants were kept on ice and transported to the laboratory where they were separated into green leaves, dead leaves, and litter components. All leaves were run through an area meter (Model LI-3100, Li-Cor, Inc., Lincoln, Nebraska) and the leaf area per plant was determined. For each plot, the leaf area per plant was multiplied by the plant population to obtain a total LAI. Total LAI for the six plots were then averaged as a site-level value (details in Viña, Gitelson, NguyRobertson, \& Peng, 2011). Green leaves were measured in the same way to obtain the green LAI. Since the LAI values change gradually during the growing season, daily total LAI and green LAI values were interpolated based on measurements on sampling dates for each site in each year.

\subsection{Fraction of absorbed photosynthetically active radiation (PAR) by the canopy}

In this study, Li-Cor quantum sensors (LI-COR Inc., Lincoln, Nebraska) were placed in each study site to collect hourly measurements of incoming PAR ( $\left.\mathrm{PAR}_{\mathrm{in}}\right)$, PAR reflected by the canopy and soil (PAR out), PAR transmitted through the canopy ( $P_{\text {transm }}$ ) and PAR reflected by the soil $\left(\mathrm{PAR}_{\text {soil }}\right)$. $\mathrm{PAR}_{\text {in }}$ was measured using point quantum sensors 6 $\mathrm{m}$ above the surface pointing towards the sky; PAR $_{\text {out }}$ was measured with point quantum sensors aimed downward, and placed at $6 \mathrm{~m}$ above the ground; $\mathrm{PAR}_{\text {transm }}$ was measured with line quantum sensors placed at about $2 \mathrm{~cm}$ above the ground, pointing upward; and $\mathrm{PAR}_{\text {soil }}$ was measured with line quantum sensors placed about $12 \mathrm{~cm}$ above the ground, pointing downward (details in Burba, 2005; Hanan et al., 2002). All daily values of radiation were computed by integrating the hourly measurements during a day when $\mathrm{PAR}_{\text {in }}$ exceeded $1 \mu \mathrm{mol} / \mathrm{m}^{2} / \mathrm{s}$. Daily values of fraction of absorbed PAR (fAPAR) were calculated as a ratio of daily absorbed PAR (APAR) to daily PAR in $_{\text {(Goward \& }}$ Huemmrich, 1992; Viña \& Gitelson, 2005):

$\mathrm{fAPAR}_{\text {total }}=\mathrm{APAR} / \mathrm{PAR}_{\text {in }}=\left(\mathrm{PAR}_{\text {in }}-\mathrm{PAR}_{\text {out }}-\mathrm{PAR}_{\text {transm }}+\mathrm{PAR}_{\text {soil }}\right) / \mathrm{PAR}_{\text {in }}$.

PAR data were collected near the eddy covariance tower in each site. PAR measurements in two closely located sites (1 and 2) were compared to understand whether the PAR data were spatially representative for the entire site. The comparison shows that during entire growing season PAR in two sites correlated very closely: $\mathrm{R}^{2}$ was above 0.99 , slope of best fit function was 1.01 and the coefficient of PAR variation between two sites did not exceed $1 \%$.

During the vegetative stage, fAPAR $_{\text {total }}$ increased coinciding with the increase of canopy green LAI. However, during the reproductive stage fAPAR total remained insensitive to decreases in crop greenness (e.g., Gallo et al., 1985; Hatfield et al., 1984). That is because in this stage both photosynthetic and non-photosynthetic components were intercepting $\mathrm{PAR}_{\mathrm{in}}$, which was progressively less used for photosynthesis (Hall et al., 1992; Viña \& Gitelson, 2005). Therefore, to obtain a measure of the fAPAR absorbed only by the photosynthetic component of the vegetation, fAPAR green was calculated as (Hall et al., 1992):

$\mathrm{PAR}_{\text {green }}=\mathrm{fAPAR}_{\text {total }} \times($ green LAI/total LAI $)$.

\subsection{Canopy reflectance at close range and in situ measured NDVI}

Spectral reflectance measurements were carried out at canopy level using hyperspectral radiometers mounted on "Goliath", an all-terrain sensor platform (Rundquist, Perk, Leavitt, Keydan, \& Gitelson, 2004). A dual-fiber optic system, with two inter-calibrated Ocean Optics USB2000 radiometers, was used to collect radiometric data in the range $400-1100 \mathrm{~nm}$ with a spectral resolution of about $1.5 \mathrm{~nm}$. One radiometer, equipped with a $25^{\circ}$ field-of-view optical fiber and kept at a constant height (around $6 \mathrm{~m}$ ) above the top of canopy throughout the growing season, was pointed downward to measure the upwelling radiance of the crop. The other radiometer, equipped with a cosine diffuser, providing a hemispherical field of view, was pointed upward to simultaneously measure incident downwelling irradiance. Measurements were collected close to solar noon (between 11:00 and 13:00 local time), when changes in solar zenith angle were minimal. Percent reflectance was then calculated based on simultaneously measured radiance and irradiance (Gitelson et al., 2006; Viña et al., 2011). For each study site, six randomly selected plots were established along the pivot roads of site 1 and site 2 and along an entrance road of site 3 (Viña et al., 2011), each with six randomly selected sampling points (details in Viña et al., 2004). Thus, a total of 36 points within these areas were sampled per site at each data acquisition. Their median value was used as the site reflectance, which has been shown to be representative of the whole field (Gitelson, Viña, et al., 2006; Viña et al., 2011).

From 2001 to 2007, canopy reflectance was measured one or two times per week during the growing seasons and every 10 days in 2008. This resulted in a total of 314 reflectance spectra for maize ( 47 in 2001, 30 in 2002, 92 in 2003, 30 in 2004, 53 in 2005, 13 in 2006, 40 in 2007 and 9 in 2008) and 145 spectra for soybean (54 in 2002, 49 in 2004, 26 in 2006 and 16 in 2008), which represented the wide range of fAPAR green variation found in maize and soybean.

The site spectra were resampled to spectral bands of MODIS $250 \mathrm{~m}$ reflectance data (red band: $620-670 \mathrm{~nm}$ and NIR band: 841-876 nm), and in situ NDVI was calculated as: NDVI $=\left(\rho_{\mathrm{NIR}}-\rho_{\text {red }}\right) /\left(\rho_{\mathrm{NIR}}+\rho_{\text {red }}\right)$, where $\rho_{\text {red }}$ is the red band reflectance and $\rho_{\text {NIR }}$ is the NIR band reflectance.

\subsection{MODIS-retrieved NDVI}

In this study, we used the MODIS NDVI product (MOD 13 - Gridded Vegetation Indices) retrieved from MODIS $250 \mathrm{~m}$ surface reflectance data (MOD09Q1 and MOD09A1). Even though the surface reflectances used to calculate NDVI were atmospherically corrected, the observed NDVI time-series is liable to include various residual noise components resulting in an erratic time series behavior and many sharp declines in NDVI values, which is due to the moderate spatial resolution $(250 \mathrm{~m})$ and wide range in view angles $\left( \pm 55^{\circ}\right)$ of MODIS. The irregular temporal features in the NDVI time series data are caused by persistent and residual, sub-pixel cloud cover, bidirectional reflectance distribution function effects, and mixed-pixel effects. Therefore, a wavelet based filter was applied for removing the high-frequency noise components to produce a daily and smoothed NDVI profile based on the linear interpolation of unequally-spaced observations of MODIS 8-day composite products (Sakamoto, Gitelson, Wardlow, Verma, \& Suyker, 2011; Sakamoto et al., 2010). The site-level NDVI values were calculated by averaging the per-pixel values within the study site, three pixels for each site (details in Sakamoto, Gitelson, \& Arkebauer, 2013). From 2001 to 2008, daily MODIS NDVI during growing seasons (around 150 observations per year) were compared with fAPAR green measurements in the field. 


\subsection{Simulation of reflectance and $f A P A R_{\text {green }}$}

As a tool for describing the seasonal patterns in the observations, we used the SAIL (Scattering from Arbitrarily Inclined Leaves) canopy reflectance model to illustrate how physical changes in canopy characteristics, such as total LAI and fractions of green and dead leaves, affect spectral reflectance and $\mathrm{fAPAR}_{\text {green }}$ for maize canopies. SAIL calculates radiative transfer within a canopy made up of uniform horizontal layers of infinite extent (Alexander, 1983; Verhoef, 1984). In the model canopy characteristics are described by the amount, orientation, and optical properties of the materials within each layer. In this study, the simulated canopy was divided into five horizontal layers, each layer containing mixtures of green and dead leaves. Leaf optical properties followed baseline values used in Goward and Huemmrich (1992) for green leaves (reflectance and transmittance for the visible band were 0.05 and for the near infrared (NIR) band were 0.48 ), with dead leaves having visible reflectance and transmittance of 0.25 and the NIR reflectance remaining the same as for green leaves (0.48). All leaves had a spherical leaf inclination angle distribution. From the model we determined nadir viewed visible and NIR reflectance, using them to calculate NDVI. The model also calculated visible transmittance, soil reflectance, and hemispheric reflectance for the canopy, which was combined with the fraction of green LAI to calculate fAPAR green using Eqs. (1) and (2) as described for the field measurements (Goward \& Huemmrich, 1992).

SAIL inputs were varied to simulate the general seasonal growth patterns observed in maize. To simulate springtime green-up stage, total LAI values were varied, with green LAI increasing from 0.05 to 5 and dead LAI held constant at 0.05 . The leaves were evenly distributed among the five layers. Note that within the SAIL model there is no explicit description of canopy height or depth of the layers, so the increasing height of the growing plants did not have to be described in the model.

For the reproductive stage the simulation of total LAI (i.e. the sum of the green LAI and dead LAI) was held constant at 5.05, but the proportions of green and dead leaves were changed. The series begins with all five layers the same and each layer having green LAI of 1 and dead LAI of 0.01 . Next, in the bottommost layer was changed to green LAI of 0.5 and dead LAI of 0.51 . Then the bottommost layer was changed to green LAI of 0.01 and dead LAI of 1 . This process was continued working upward through each layer in the canopy.

\subsection{Statistic metrics}

Both in situ NDVI and MODIS NDVI were compared with corresponding daily fAPAR green, and the best-fit-function of fAPAR green vs. NDVI relationship was established. Besides the coefficient of determination $\left(\mathrm{R}^{2}\right)$ and standard error (SE), noise equivalent was also calculated to assess the accuracy of estimating fAPAR green by NDVI. The noise equivalent is a measure of how accurately NDVI responds to a change of APAR $_{\text {green }}$ across its entire dynamic range, considering both the slope and scattering of the points from the best fit function (Viña \& Gitelson 2005):

$\mathrm{NE}\left(\Delta \mathrm{fAPAR}_{\text {green }}\right)=\mathrm{SE}\{\mathrm{NDVI}$ vs.fAPAR $\mathrm{freen}\} /\left(d(\mathrm{NDVI}) / d\left(\mathrm{fAPAR}_{\text {green }}\right)\right.$

where $d(N D V I) / d\left(\right.$ fAPAR $\left._{\text {green }}\right)$ is the first derivative of the best fit function of the relationship NDVI vs. fAPAR ${ }_{\text {green }}$, and SE $\left\{\right.$ NDVI vs. fAPAR $\left._{\text {green }}\right\}$ is standard error of the best fit function of this relationship.

\section{Results and discussion}

\subsection{Relationship fAPAR vs. in situ measured NDVI}

The relationship between fAPAR $_{\text {green }}$ and NDVI, taken at close range during eight growing seasons in three irrigated and rainfed sites, was nonlinear and NDVI was almost invariable when fAPAR green exceeded 0.65 (Fig. 1). There were no significant differences in the relationships for different crop species (maize and soybean) studied.

Noise equivalent of fAPAR green, $\mathrm{NE}\left(\triangle \mathrm{fAPAR} \mathrm{R}_{\text {green }}\right)$, varied widely as fAPAR $_{\text {green }}$ changed and was very different for maize and soybean (Fig. 2). In the very beginning of the growing season it was around 0.25 for soybean and much lower, 0.07 , for maize, and then dropped to 0.13 for soybean and to 0.05 for maize as crop density increased. It varied slightly as fAPAR green was between 0.2 and 0.6 and then increased drastically up to 0.35 for soybean and 0.25 for maize as $\mathrm{fAPAR}_{\text {green }}$ exceeding 0.6. High values of $\mathrm{NE}\left(\triangle \mathrm{fAPAR}_{\text {green }}\right)$ in the beginning of the season are due to variable reflectance of soils and residue, as well as uncertainties of fAPAR measurements in sparse canopies. The increase of $\mathrm{NE}\left(\triangle \mathrm{fAPAR}_{\text {green }}\right)$ for fAPAR green $>0.6$ is due to saturation of NDVI at high canopy density (e.g., Buschmann \& Nagel, 1993; Gitelson \& Merzlyak, 1994; Myneni, Nemani, \& Running, 1997). For NDVI values between 0.8 and 0.9 , fAPAR green may vary from 0.65 to 0.9 , thus bringing large uncertainties to fAPAR $_{\text {green }}$ estimation using NDVI (Fig. 1).

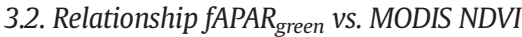

The data collected in situ at close range covered 8 years of observations and over that time reflectance measurements were taken with varying frequencies - from two times per week to one time per week and three times per month. These data did provide a general nonlinear characterization of fAPAR green/NDVI relationships for the two crops but this limited data set was not sufficient to resolve fine details in these relationships, especially differences between the vegetative stage when the crop canopy is vertically homogeneous and leaves are "homogeneously green" and the reproduction stage when leaf chlorophyll content declines and vertical distribution of leaf chlorophyll content and green leaf area change drastically (Ciganda et al., 2012, 2008). In maize and soybean canopies, vertical distributions of green leaf area index and leaf chlorophyll content are very different (Gitelson et al., 2005; Viña et al., 2011). The vertical distribution of chlorophyll content in maize is bell-shaped in both stages of development, vegetative and reproductive, while in soybean canopies the variability in leaf chlorophyll content is much less pronounced than in maize. These

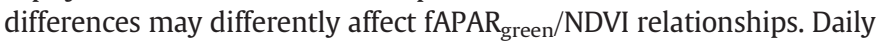
MODIS data are very suitable for such analysis by allowing the study

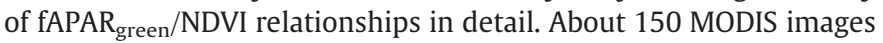
were collected during each growing season from May to October while the maximal number of in situ reflectance observations taken during the growing season was only 33 .

The first step was to investigate the fAPAR $_{\text {green}} / \mathrm{NDVI}$ relationships for different crop development stages: vegetative and reproductive. Vegetative stage is the period when green LAI and leaf chlorophyll content increases to the maximum value (with LAI around 6 for maize and 5 for soybean, and leaf chlorophyll content about $500-600 \mathrm{mg} / \mathrm{m}^{2}$ ) while the reproductive stage starts when green LAI and leaf chlorophyll content decreases towards senescence. In Fig. 3A the fAPAR green/NDVI relationship is presented for the rainfed maize site in 2003. In the spring during the vegetative stage all leaves were green, and the fAPAR green $_{\text {/ }}$ NDVI relationship was linear with slight saturation in the end of the stage. The determination coefficient $\left(R^{2}\right)$ of a linear relationship was very high, with $R^{2}=0.97$ and the number of samples $(n)=42$. In the beginning of the reproductive stage, starting with the maximum

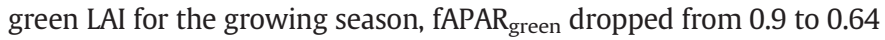
(denoted as $\triangle$ fAPAR $_{\text {green }}$ in Fig. $3 \mathrm{~A}$ ) while NDVI remained almost invariable changing from 0.82 to 0.85 . Later in the season, the decrease of fAPAR $_{\text {green }}$ was virtually synchronous with the decrease of NDVI and a slope of this relation was quite close to that in the vegetative stage.

To understand the reason for hysteresis in the fAPAR green/NDVI relationship in maize, the temporal behaviors of NDVI, fAPAR green $_{\text {and }}$ green LAI were studied (Fig. 3B). Four different phases were observed during the whole growing season as shown in Fig. 3B. Phase 1: 


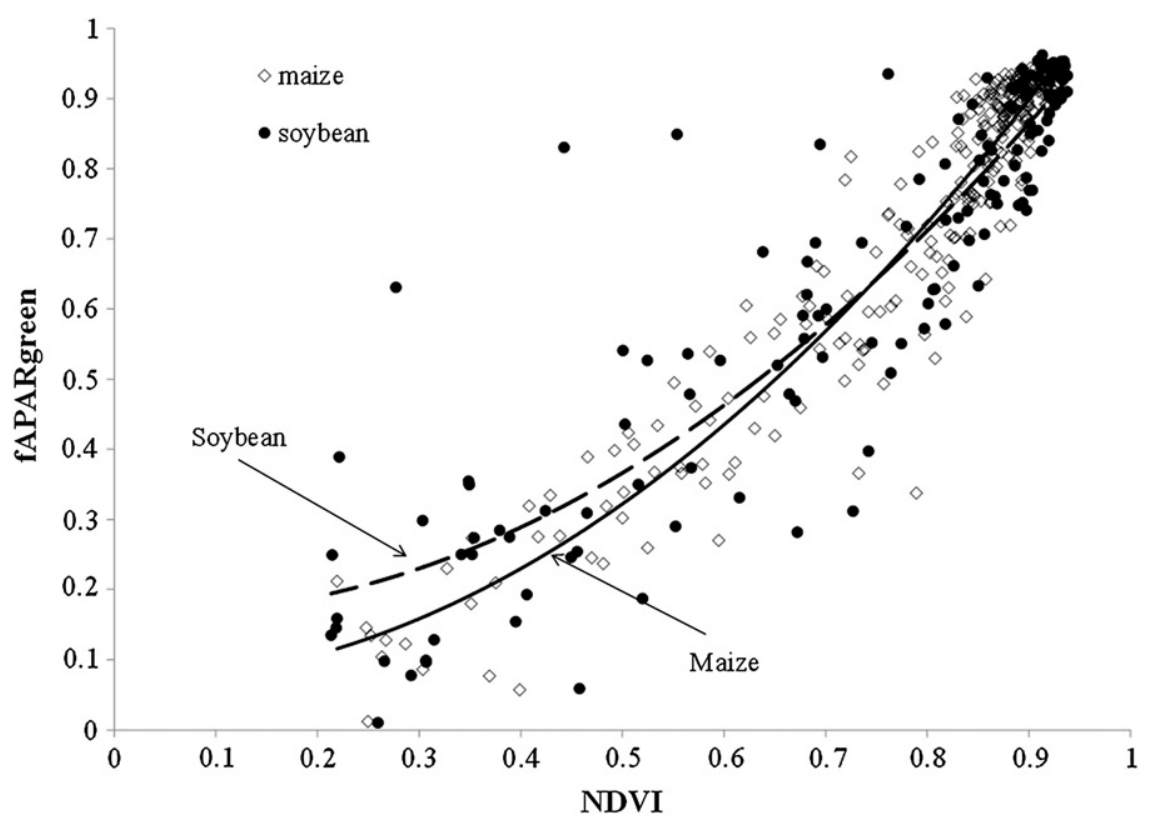

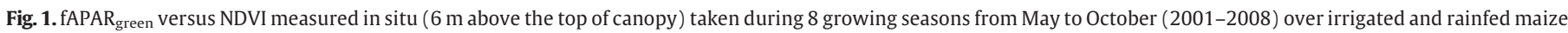
(16 sites $*$ years) and soybean ( 8 sites $*$ years). NDVI was calculated in simulated spectral bands of MODIS.

fAPAR $_{\text {green }}$ and NDVI increased almost synchronously (green $\mathrm{LAI}<3$, fAPAR $_{\text {green }}<0.70$, day of year (DOY) $<195$ ) with slight decrease in slope as green LAI exceeded 3 (DOY around 185 to 195); Phase 2: fAPAR $_{\text {green }}$ and green LAI increased up to maximal values but NDVI slightly decreased ( $\triangle \mathrm{NDVI}=0.04$, DOY from 195 to 210); Phase 3: fAPAR $_{\text {green }}$ and green LAI decreased $\left(\triangle \mathrm{fAPAR}_{\text {green }}>0.3, \Delta\right.$ green LAI > 1.2) but NDVI remained invariant (DOY from 210 to 225); and Phase 4: green LAI dropped sharply, fAPAR green $_{\text {and NDVI decreased }}$ synchronously (Fig. 3B).

In the first phase, crop density increased and both NDVI and green LAI increased up to around DOY 195 (Fig. 3C), when rate of the increase in NDVI was lower than that of green LAI, resulting from the insensitivity of NDVI to moderate to high green LAI. This type of saturation of the relationship between NDVI and green LAI (as green LAI above 2-3) was reported for obviously nonlinear relationships simulated by radiative transfer models (e.g., Myneni et al., 1997) as well as observed in empirical studies (Asrar et al., 1984; Gitelson, Gritz, \& Merzlyak, 2003; Hatfield et al., 1984). It is due to saturation of red reflectance and the very formulation of normalized-difference indices that made NDVI becoming insensitive to high vegetation density when $\rho_{\mathrm{NIR}} / \rho_{\text {red }} \gg 1$ (Gitelson, 2004, 2011).

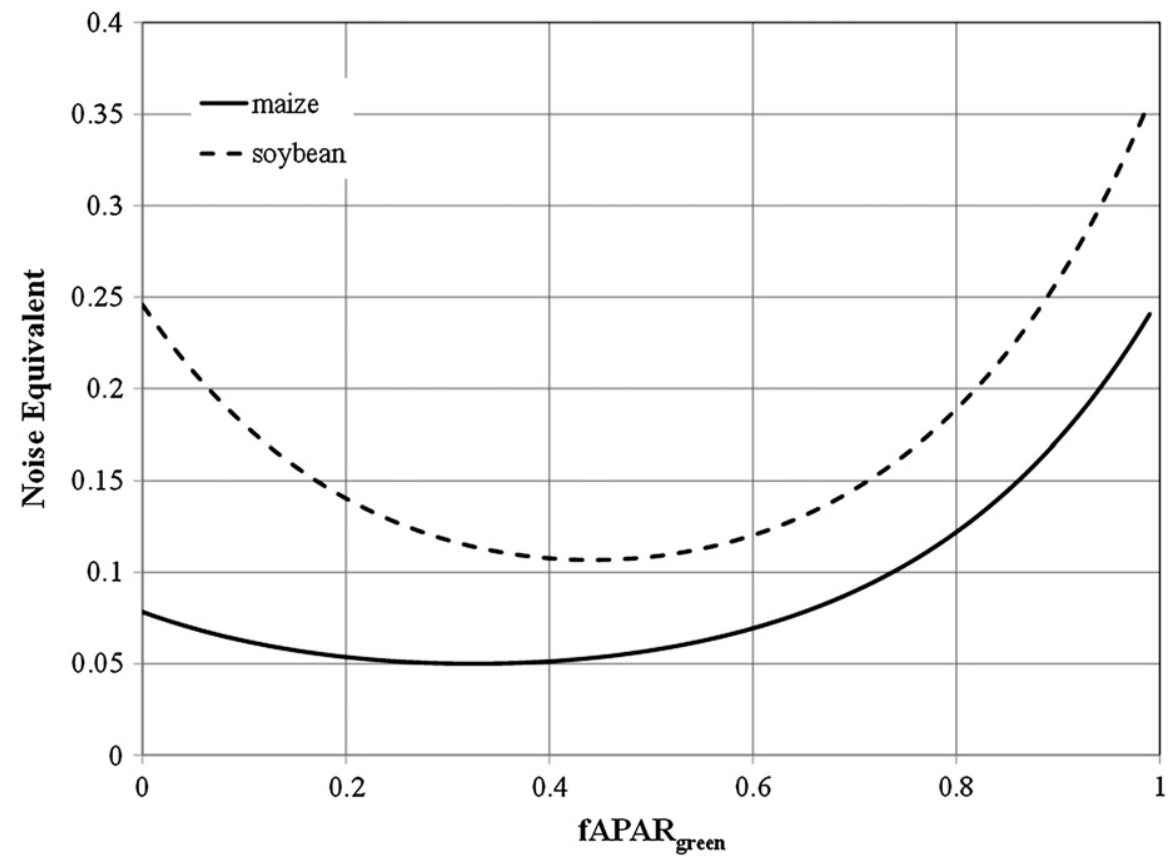

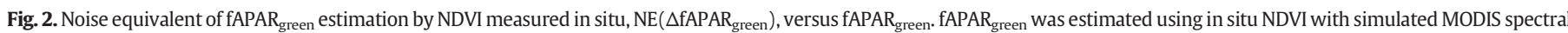
bands. 


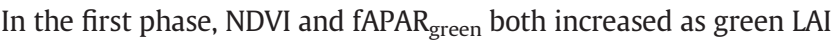
increased (Fig. 3B), however, when fAPAR green exceeded 0.6, the rate of fAPAR green increase was higher than that of NDVI due to the insensitivity of NDVI to moderate-to-high vegetation greenness. In this phase,

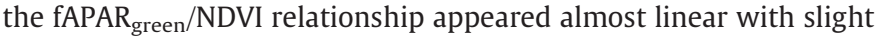
decrease in slope when fAPAR $_{\text {green }}>0.6$ (Fig. 3A).

In the second phase (around DOY 195), crop density was at its highest with maximal total chlorophyll content and green LAI. NDVI reached maximal values of around 0.9 as green LAI exceeded 2 . Then with the increase of green LAI, NDVI remained virtually invariant (Gitelson et al., 2003; Guindin-Garcia, Gitelson, Arkebauer, Shanahan,
\& Weiss, 2012; Viña et al., 2011) with only slight decrease due to tassel appearance (Viña et al., 2004). Thus, the relationship fAPAR green/NDVI in this phase appeared scattered with a little loop of slightly increased fAPAR $_{\text {green }}$ but decreased NDVI (Fig. 3a).

In the third phase, beginning of reproductive stage, DOY 210 through 225, fAPAR green decreased from 0.85 to 0.65 while NDVI remained invariant ( $\triangle \mathrm{fAPAR}=0.3$, Fig. $3 \mathrm{~B})$. NDVI was also insensitive to a change of green LAI from 4.1 to 2.9 (denoted as $\triangle$ green LAI in Fig. $3 B$ ). The decrease of fAPAR green and green LAI with no change in NDVI during this phase of the season in maize is mainly due to leaves in the bottom of canopy drastically losing chlorophyll content while
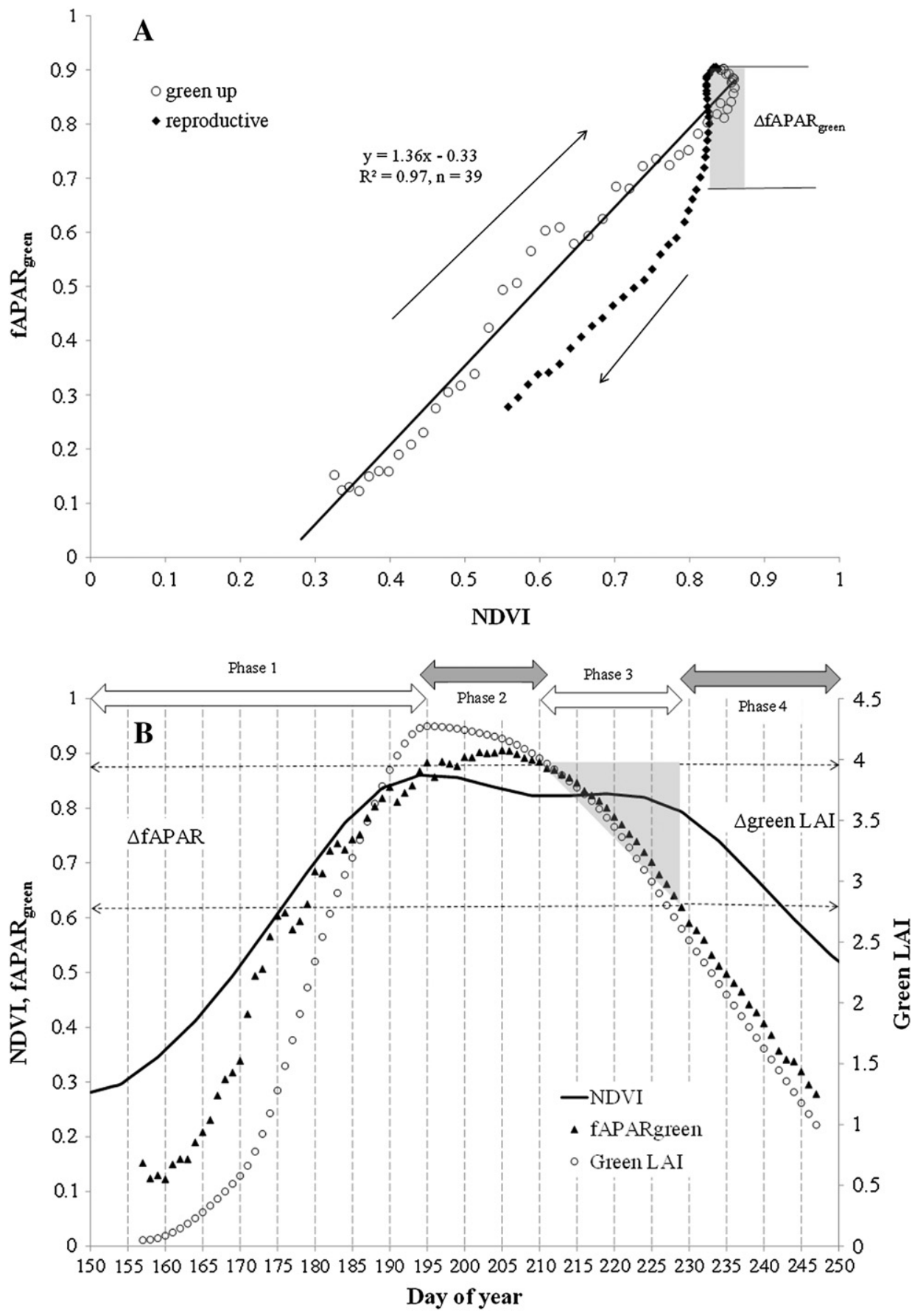

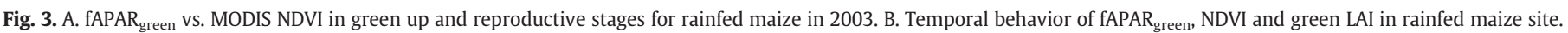
C. Relationship fAPAR green Vs. NDVI, simulated by SAIL model in MODIS bands for maize in vegetative and reproductive stages. 


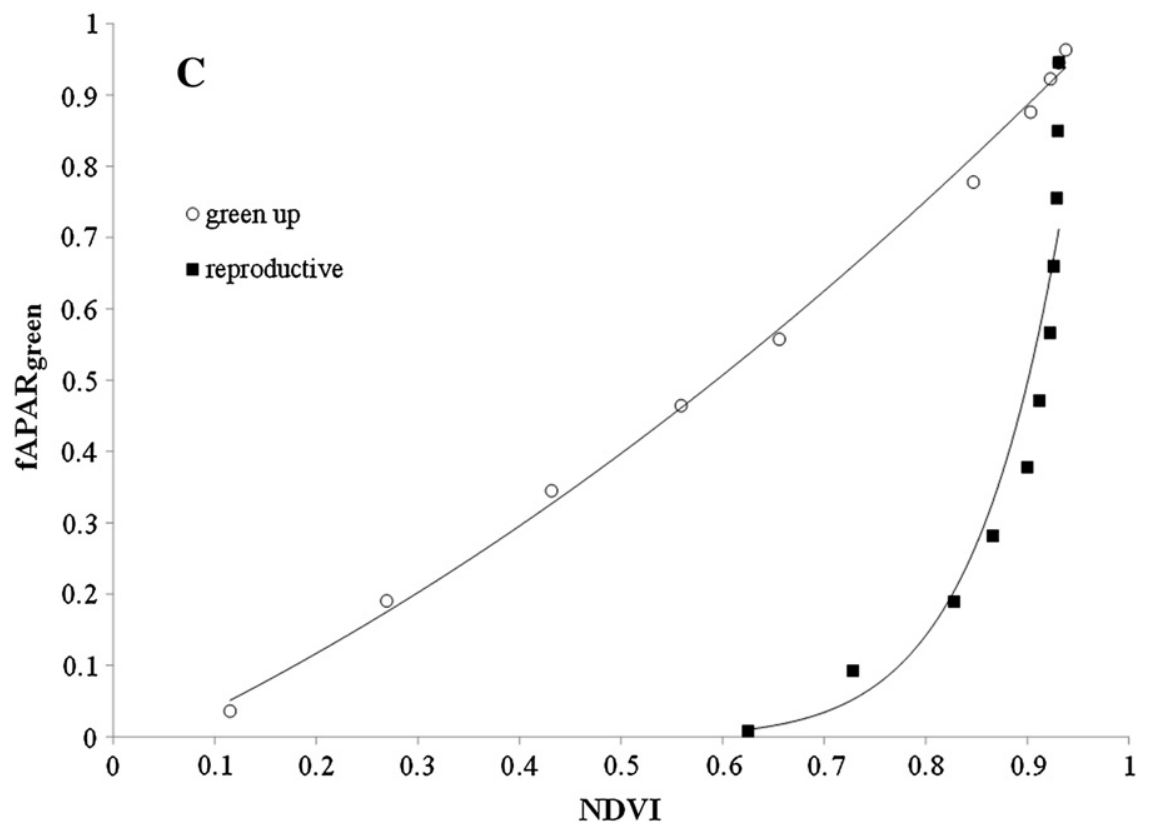

Fig. 3 (continued).

leaves at the top of the canopy remain green (Ciganda et al., 2012, 2008). Red light does not penetrate deeply into these canopies, with red reflectance coming mostly from the top layers of the canopy, so the loss of chlorophyll content in the lower layers has little effect on canopy red reflectance. But the decrease of chlorophyll content at the lower canopy layers affects the green LAI of the whole canopy, thus the decrease shows up in the fAPAR green calculation (Fig. 3B). Meanwhile for NIR, mainly affected by scattering by leaves, light penetrates to deeper layers. So, the total LAI remained almost the same but the loss of greenness does not affect NIR reflectance much and it has only small changes. Therefore, at this phase of the beginning in the reproductive stage, when top layer of leaves remained green, NDVI was invariant as fAPAR green decreased significantly.

In the fourth phase with DOY $>225$, leaf chlorophyll content decreases in the whole canopy and maize leaf inclination changes drastically due to leaves breaking and hanging free, fAPAR green, green LAI and NDVI decrease synchronously (Fig. 3B).

In SAIL model simulations, keeping green LAI in the top layer of the canopy constant while varying green LAI in the bottom layer as in third phase, generated fAPAR green Vs. NDVI relationship (Fig. 3C) clearly showed the existence of the hysteresis revealed in the empirical data (Fig. 3A).

The fAPAR green/NDVI relationship for soybean was found to be even more nonlinear than in maize (Fig. 4A). Temporal behavior of NDVI, fAPAR $_{\text {green }}$ and green LAI was studied to understand features of the fAPAR $_{\text {green }}$ /NDVI relationship (Fig. 4B). Five distinct phases of temporal behavior of NDVI and fAPAR green were observed in soybean. In the first phase (DOY $<210$ ), as green LAI was below 2 and APAR $_{\text {green }}$ below 0.7 , NDVI followed the increase of fAPAR $_{\text {green }}$ and the $\mathrm{fAPAR}_{\text {green }} / \mathrm{NDVI}$ relationship was fairly linear. In the second phase (DOY around 210 to 220), LAI reached 3.5 and fAPAR $_{\text {green }}$ increased at the same rate as in the first phase, but the rate of NDVI increase dropped and the slope of

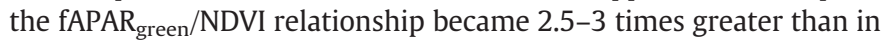
the first phase. This observations of soybean were similar to the first phase in maize, but with a much more obvious saturation of NDVI in soybeans.

In the third phase (DOY around 220 to 240), green LAI and leaf chlorophyll content increased to maximal value and NDVI slightly increased, but fAPAR green was virtually invariant. The slope of the APAR $_{\text {green }} / \mathrm{NDVI}$ relationship drops 10 -fold, to below one - the relationship became almost horizontal (Fig. 4A). In the fourth phase (DOY around 240 to 250 ), while both green LAI and NDVI decreased ( $\triangle$ green LAI $=0.8$, $\Delta \mathrm{NDVI}=0.13)$, fAPAR $_{\text {green }}$ remained almost constant $\left(\triangle \mathrm{fAPAR}_{\text {green }}=\right.$

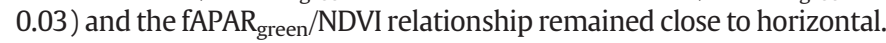
In the fifth phase (DOY > 250), both fAPAR $_{\text {green }}$ and green LAI sharply decreased and NDVI followed them similar to the fourth phase in maize canopy.

Thus, soybean $\mathrm{fAPAR}_{\text {green }}$ was almost invariant in the third phase, when green LAI and NDVI increased, and also in the fourth phase, when both green LAI and NDVI decreased. It caused an almost horizon-

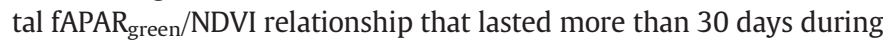
growing season. The likely reason is very different soybean canopy structure from a maize canopy. Unlike a maize canopy that is "open" to incident light, allowing a significant fraction of incident light to penetrate directly inside the canopy, the soybean canopy is much more "closed" to light penetration. In addition, in a maize canopy, leaf chlorophyll content and green LAI gradually increases from the top of canopy, reaching maximal values in the middle of canopy around ear leaf (Ciganda et al., 2008). Thus, leaf transmittance in the upper maize leaf layers is much higher than in the top soybean leaves; together with an "open" canopy structure, it supports high light levels in the middle of a maize canopy. In a soybean canopy, leaf chlorophyll content is distributed more evenly than in maize - in the upper canopy layer it is almost as high as in the lowest layers. The light transmitted by upper leaf layer inside the canopy is only $1-2 \%$ in the blue and red ranges of the spectrum and does not exceed 3-5\% in the green (Gitelson, Keydan, \& Merzlyak, 2006). Thus, for soybean in the third phase, at the end of vegetative stage when leaf chlorophyll content was maximal, the depth of light penetration (that is inversely proportional to the product of leaf absorption and penetration depth, Merzlyak \& Gitelson, 1995) was somewhat limited by upper leaf layers.

Soybean's "closed" canopy structure is probably the main cause of

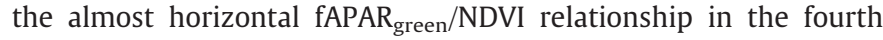
phase. In the beginning of the reproductive stage with decreasing leaf chlorophyll content (absorption by top leaves decreased and transmittance increased), the depth of light penetration inside the soybean canopy increased, more radiation penetrated deeper inside the canopy and was intercepted by the lower leaf layers. Thus, fAPAR green $_{\text {remained as }}$ high as in the third phase when leaf chlorophyll content and green LAI were higher. 

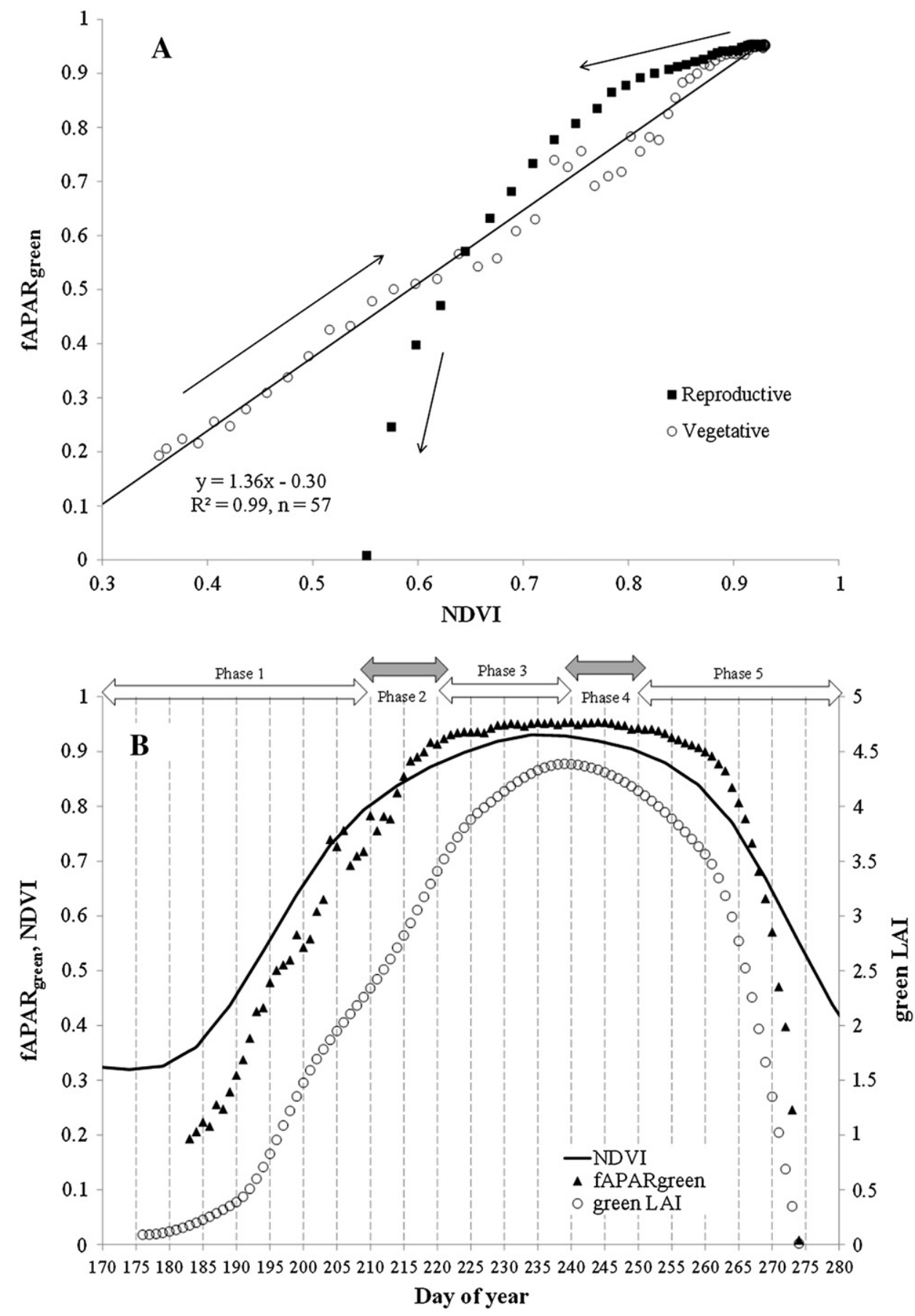

Fig. 4. (A) fAPAR $_{\text {green }} / \mathrm{NDVI}$ relationships and (B) temporal behavior of fAPAR ${ }_{\text {green }}$, NDVI and green LAI in irrigated soybean site.

To the best of our knowledge, this phenomenon has not been studied and explained. It is probably because very high temporal resolution data are required to detect this behavior. We were not able at this stage to make up a set of SAIL inputs that described a reasonable seasonal growth pattern that also produced NDVI/fPAR green patterns that match our observations, as we were able to do with maize. To do that one needs detailed seasonal leaf chlorophyll distribution in canopy to test the hypothesis with a model. It remains to be seen whether the results of reflectance and APAR $_{\text {green }}$ simulation by radiative transfer models (e.g., Darvishzadeh, Skidmore, Schlerf, \& Atzberger, 2008; Koetz, Baret, Polive, \& Hill, 2005) for soybean-like canopy structure with variable leaf chlorophyll content correspond to experimental data and our hypotheses would be confirmed.

\section{3. fAPAR $_{\text {green }} / N D V I$ relationships in different years}

For maize, the fAPAR green/NDVI relationships collected over 8 years at three test sites are presented in Fig. 5A. While the relationships were nonlinear at the top of season, the best fit functions for each stage of crop development, vegetative and reproductive, was linear with $\mathrm{R}^{2}$ above 0.93, allowing for estimating of fAPAR green $_{\text {using MODIS-retrieved NDVI }}$ with standard error (SE) below 0.059. Importantly, in vegetative and reproductive stages the slopes of the relationships were very different, greatly increasing uncertainties of fAPAR $_{\text {green }}$ estimation using one algorithm over the season without re-parameterization for different stages. Thus, to estimate fAPAR green more accurately, at least two algorithms parameterized for each stage are required. 
For soybean, relationships in vegetative and reproductive stages were even more complex than in maize (Fig. 5B). In the vegetative stage, despite distinct hysteresis (Fig. 4A and B), the determination coefficient of a linear relationship was high $\left(R^{2}=0.94\right)$ allowing for fAPAR $_{\text {green }}$ estimation with SE below 0.07 . However, in the reproductive stage, due to much more pronounced hysteresis, the points were scattered widely from a nonlinear best fit; $\mathrm{R}^{2}$ was 0.79 and STD of fAPAR $_{\text {green }}$ estimation above 0.17 . Such scattering of soybean samples was also observed in the data taken at close range (Fig. 1). The difference in slopes in both stages prevented accurate assessment of fAPAR $_{\text {green }}$ during whole growing season.

In the vegetative stage, despite great differences in leaf inclination and leaf structure (C3 vs. C4), the fAPAR green/NDVI relationships in maize and soybean were quite close with only slight differences in slopes and offsets (Fig. 6), allowing for estimation of the fAPAR green $_{\text {by }}$ MODIS NDVI with SE below 0.064 .

\subsection{Comparison relationships using simulated and measured NDVI}

Fig. 7 shows that the relationships for the crops studied had significantly smaller offsets than the relationships simulated using radiative transfer models by Myneni and Williams (1994) and Goward and Huemmrich (1992), and empirical relationships established for wheat (Asrar et al., 1984 and Hatfield et al., 1984), and for a wide range of plant functional types including annuals, vines, deciduous and evergreen shrubs and trees (Sims et al., 2006). The relationships established
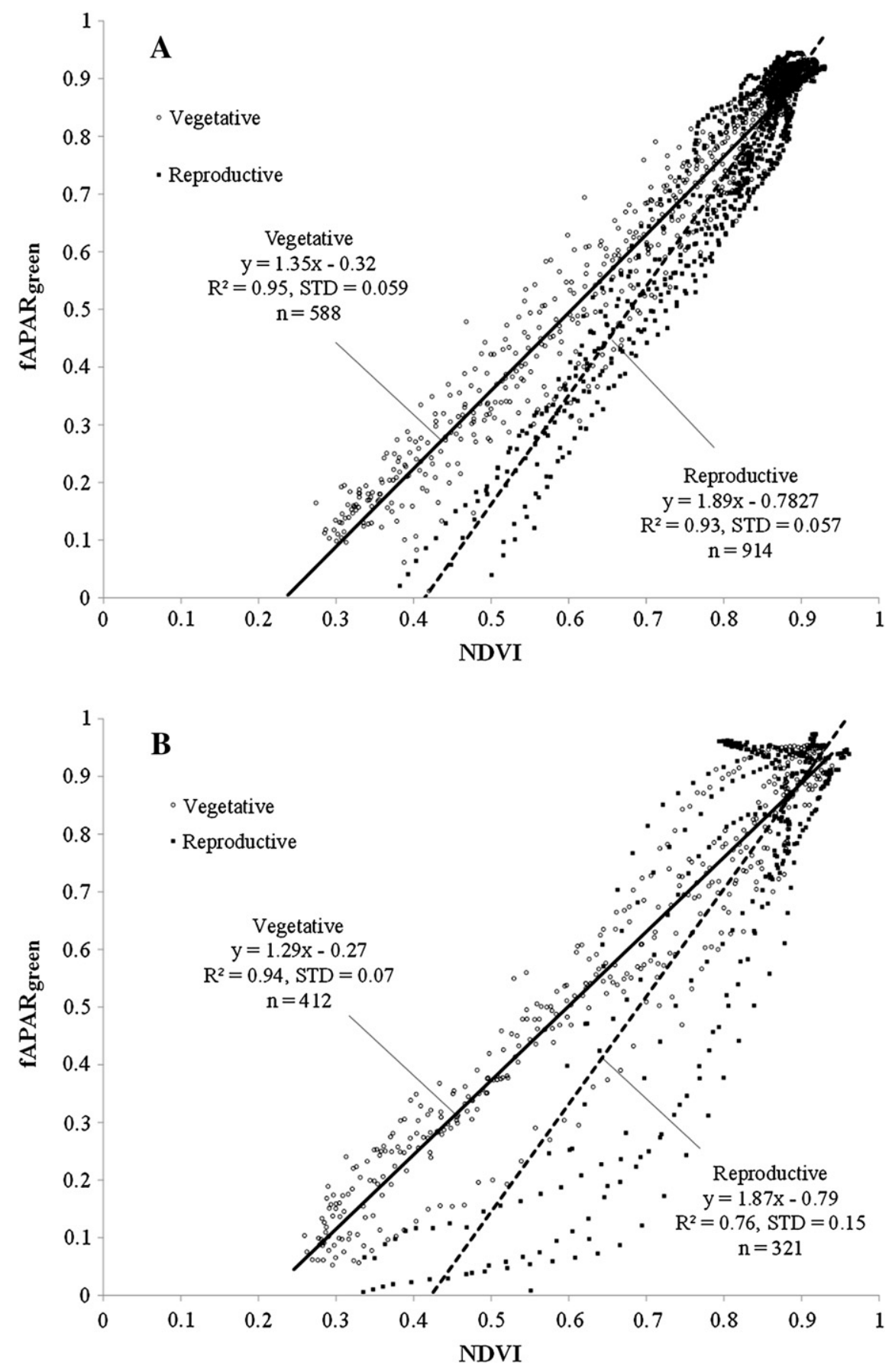

Fig. 5. MODIS NDVI vs. fAPAR green for (A) maize in 2001 to 2008 (16 sites * years) and for (B) soybean in 2002, 2004,2006 and 2008 (8 sites * years). 


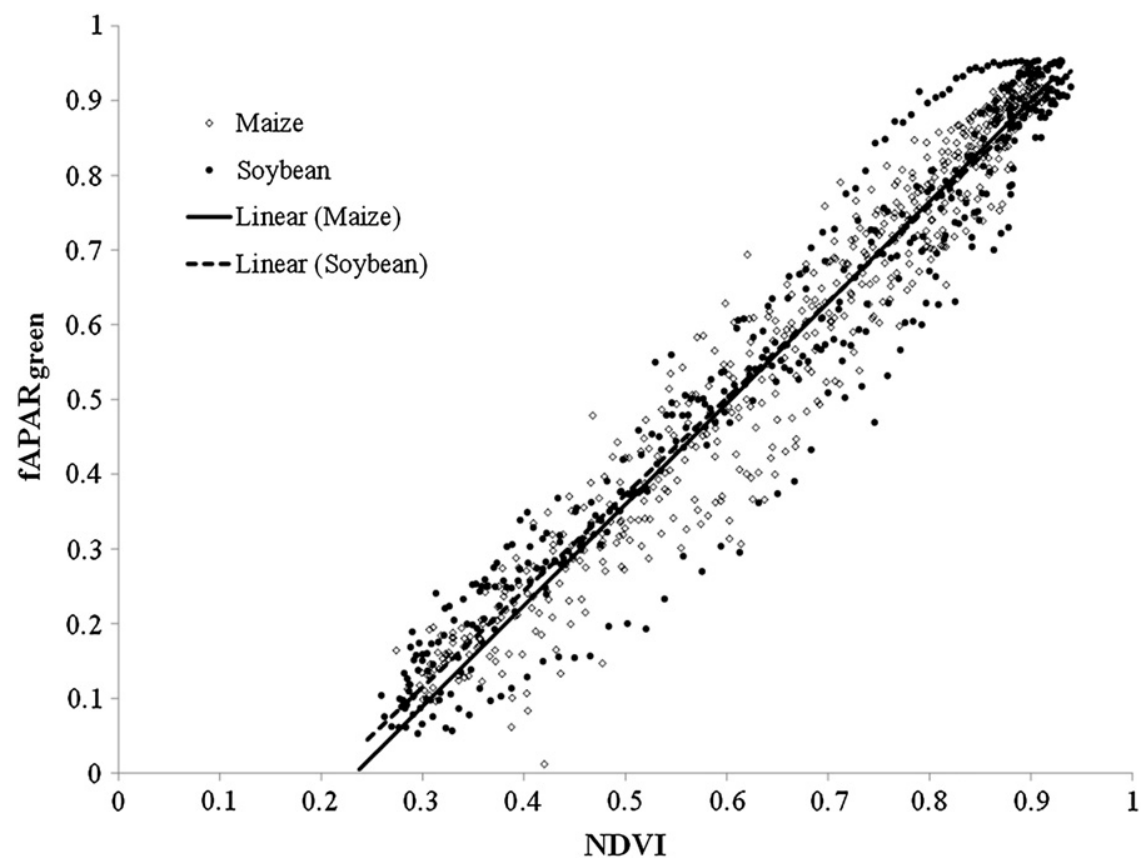

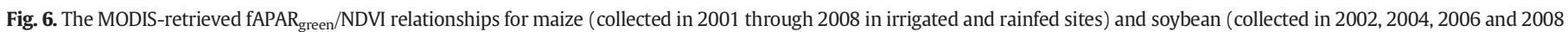
over two irrigated and rainfed sites each year) in vegetative stage. Solid and dashed lines are best fit functions.

in this study using in situ measured and MODIS-retrieved NDVI are sig-

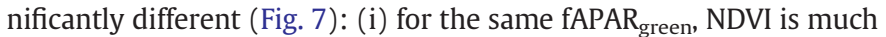
higher than predicted by both radiative transfer models and experimental data (Asrar et al., 1984; Hatfield et al., 1984; Sims et al., 2006); (ii) relationships are essentially non-linear with significant decline in sensitivity of NDVI to fAPAR green above 0.6 (for both maize and soybean, Figs. $3 \mathrm{~A}$ and $4 \mathrm{~A}$ ), and (iii) in soybean, fAPAR $_{\text {green }}$ is almost non-variable in the end of vegetative stage when both NDVI and LAI increased and in the beginning of reproductive stage as NDVI and LAI declined (Fig. 4B).
The relationships established by Fensholt et al. (2004) using in situ measured time series of both parameters (fAPAR and NDVI) over three sites in semi-arid Senegal as well as relationship established by Huemmrich et al. (2005) for woodland in western Zambia were the closest to those established in this study. However, in both of the mentioned studies the density of vegetation was much lower than that in Nebraska crops, thus, not surprisingly, the relationships presented in those works were very linear.

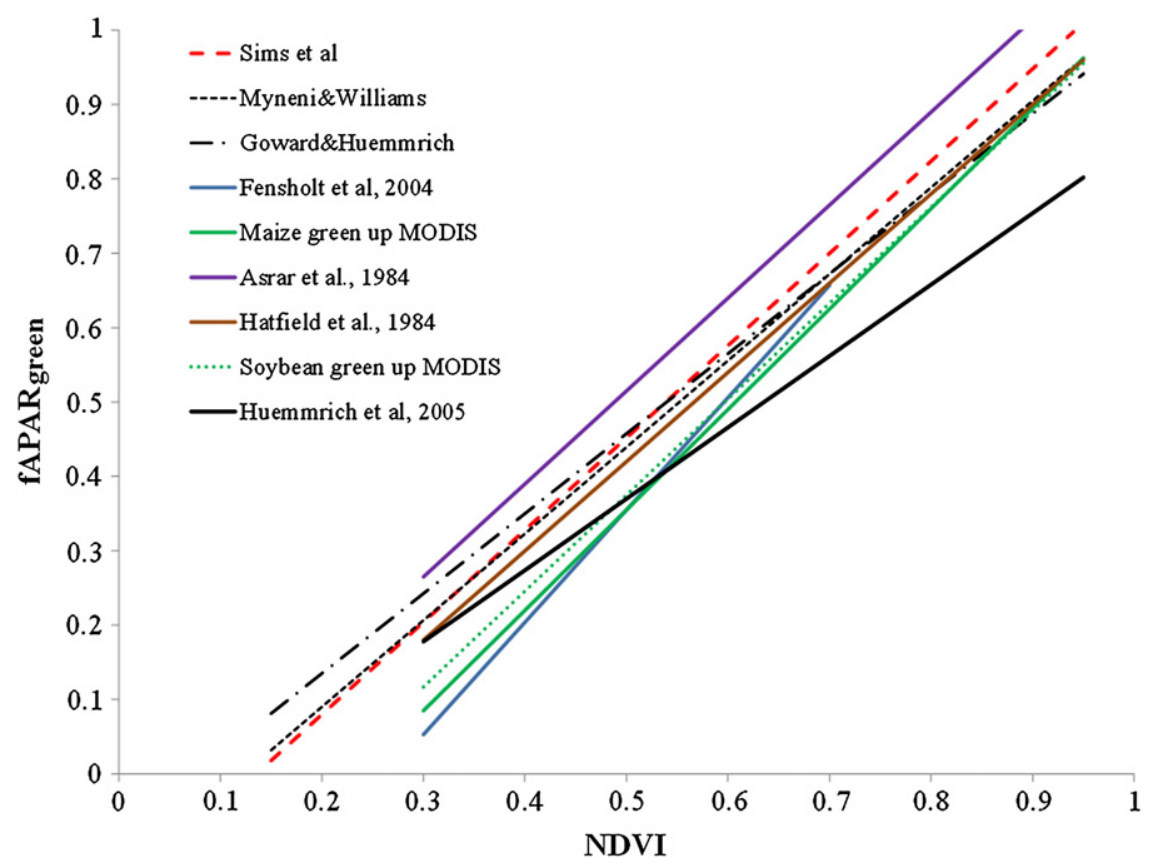

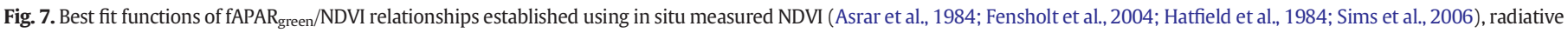

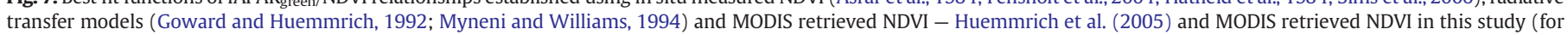
vegetative stage). The relationships fAPAR green Vs. in situ NDVI established in this study were very close to that using MODIS retrieved NDVI. 
Table 1

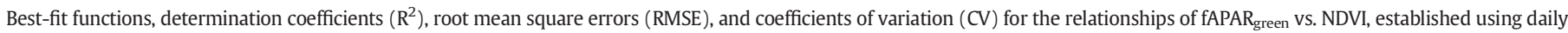
MODIS $250 \mathrm{~m}$ and in situ radiometric data, during the vegetative and reproductive stages.

\begin{tabular}{|c|c|c|c|c|c|c|c|}
\hline Crop & Stage & Data source & Sample no. & fAPAR $_{\text {green }}$ Vs. NDVI & $\mathrm{R}^{2}$ & STD & $\mathrm{CV}, \%$ \\
\hline Maize & Vegetative & MODIS $250 \mathrm{~m}$ & 588 & $\mathrm{y}=1.35 \mathrm{x}-0.32$ & 0.95 & 0.06 & 10 \\
\hline Maize & Reproductive & MODIS $250 \mathrm{~m}$ & 914 & $\mathrm{y}=1.89 \mathrm{x}-0.78$ & 0.93 & 0.06 & 8 \\
\hline Soybean & Vegetative & MODIS $250 \mathrm{~m}$ & 412 & $\mathrm{y}=1.29 \mathrm{x}-0.27$ & 0.94 & 0.07 & 13 \\
\hline Soybean & Reproductive & MODIS $250 \mathrm{~m}$ & 321 & $y=1.42 x^{3.86}$ & 0.79 & 0.17 & 24 \\
\hline Maize & Vegetative & Close range & 149 & $\mathrm{y}=1.24 \mathrm{x}-0.25$ & 0.88 & 0.08 & 11 \\
\hline Maize & Reproductive & Close range & 112 & $\mathrm{y}=1.51 \mathrm{x}-0.50$ & 0.91 & 0.07 & 9 \\
\hline Soybean & Vegetative & Close range & 93 & $y=1.01 x-0.07$ & 0.81 & 0.12 & 19 \\
\hline Soybean & Reproductive & Close range & 48 & $\mathrm{y}=1.17 \mathrm{x}^{2.62}$ & 0.84 & 0.11 & 15 \\
\hline
\end{tabular}

It must be stressed that such empirical relations between fAPAR $_{\text {green }}$ and MODIS-retrieved NDVI are dependent on solar and view zenith angle geometry and soil color variations. However, the fAPAR $_{\text {green }} /$ NDVI relations, derived from MODIS data and in situ measured NDVI at close range, were quite close. Moreover, solar and view zenith angle geometry were absolutely the same for maize and soybean sites. It resulted in close relationships for both species during the vegetative stage and contrasting differences between them in reproductive and senescence stages. The very wide range of variation of the fAPAR green/ NDVI relationships, presented in Fig. 7 for measured NDVI, as well as the large differences between simulations by radiative transfer models and in situ measurements taken during the vegetative stage in this study, showed that we are far from understanding all factors that affect this relationship.

There are sufficient causal grounds for relating fAPAR to NDVI. Top of the canopy NDVI and fAPAR increase with ground cover and plant leaf area (Myneni \& Williams, 1994). Simulations using radiative transfer models (e.g., Goward \& Huemmrich, 1992; Myneni \& Williams, 1994) showed that fAPAR to NDVI functional responses to leaf orientation, solar zenith angle and atmospheric optical depth are similar. Our results confirm this statement for crops with very contrasting leaf structures (C3 vs. C4) and canopy architectures, maize and soybean, for the vegetative stage only when fAPAR $_{\text {green }}$ was below 0.7. fAPAR green and NDVI responded differently to other parameters as it appears as very different relationships for maize and soybean in reproductive stages (Table 1). Thus, as Myneni and Williams (1994) concluded in their paper "this simplified model of the relationship between fAPAR and NDVI must be seen as a typical or an average model, for it is derived to represent a large canopy problem parameter space (ground cover, leaf area, leaf orientation, and optical properties). For this very reason, it may poorly represent the relationship between fAPAR and NDVI in a particular situation."

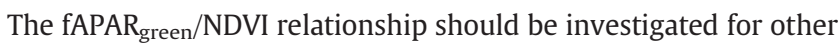
species using daily data, as used in this study. The hysteresis of this relationship may occur in crops, grasslands and deciduous forests as well. Radiative transfer models should take into account vertical heterogeneity of leaf chlorophyll content and green LAI distributions within the canopy and reveal the extent of hysteresis of the APAR $_{\text {green }} / \mathrm{NDVI}$ relationships in different species.

Thus, despite high determination coefficients of linear fAPAR green $_{\text {/ }}$ NDVI relationships, one should be aware of the essential nonlinearity of the relationships. Essentially, in the vegetative stage (excluding the very end of the stage), canopy architecture and leaf structure do not

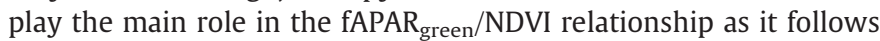
from radiative transfer simulations. However, at the top of the season in vegetative stage as well as in reproductive stage canopy architecture

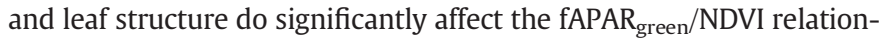
ships (Figs. 3, 4 and 5). This essential non-linearity may be source of great uncertainties in fAPAR $_{\text {green }}$ estimation. The factors affecting the $\mathrm{NDVI} / \mathrm{fAPAR}$ relationships showed in this study will also affect model inversions, complicating fAPAR $_{\text {green }}$ retrievals.

\section{Summary}

The relationships between fraction of PAR, absorbed by photosynthetically active vegetation ( fAPAR $_{\text {green }}$ ), and NDVI for two crops with contrasting leaf structures (C3 vs. C4) and canopy architectures, using in situ radiometric data and daily MODIS data, taken during eight growing seasons over three irrigated and rainfed maize and soybean sites were established. Through the use of high temporal resolution in situ and MODIS data, it was possible to identify specific phases in the growing season that aid in the interpretation of observations collected with coarser temporal resolution (or even single scenes). MODIS data are adequate for resolving distinct phases in the $\mathrm{fAPAR}_{\text {green }} / \mathrm{NDVI}$ relationships within the growing season. The identification of these different phases has important implications for the interpretation of remotely sensed observations of crops, such as the estimation of LUE and productivity.

Specifically, this paper

(a) showed that established relationships fAPAR green Vs. in situ NDVI were very close to that fAPAR green $_{\text {VS. MODIS-retrieved NDVI; }}$

(b) showed that in vegetative stage, when fAPAR green $_{\text {was }}$ welow 0.7,

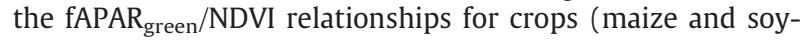
bean), contrasting in leaf structures and canopy architecture, were almost linear allowing accurate estimation of fAPAR green$_{\text {; }}$;

(c) revealed very different fAPAR green/NDVI relationships in reproductive stages for both crops, maize and soybeans, showing that canopy architecture and leaf structure greatly affect the relationship as leaf chlorophyll content changes and vertical distribution of chlorophyll content and green LAI inside the canopy becomes heterogeneous;

(d) revealed fine details of the fAPAR $_{\text {green }} / \mathrm{NDVI}$ relationships, specifically two types of hysteresis that prevent accurate fAPAR $_{\text {green }}$ estimation using NDVI during whole growing season;

(e) showed that, through SAIL model simulations, the APAR $_{\text {green }}$ / NDVI relationship for maize clearly displayed the existence of hysteresis in the relationship as revealed by empirical data; suggested that the mechanism for hysteresis in the soybean relationship should be further studied using radiative transfer models;

(f) found that the fAPAR green/NDVI relationships, established for vegetative stage in maize and soybean, are very different from other empirical studies at close range and satellite levels as well as from radiative transfer simulations. This shows the need for extensive research on remote sensing techniques for fAPAR $_{\text {green }}$ estimation.

The issues of canopy vertical heterogeneity (in terms of leaf chlorophyll content, leaf angle distribution and leaf area), studied in this paper, also affect other remote sensing problems such as estimating leaf and canopy chlorophyll content, light use efficiency and productivity. To our knowledge, there has been little work addressing the issue of 
the effects of vertical variability in canopy structure and the paper shows the importance of this.

\section{References}

Alexander, L. (1983). SAIL Canopy Model Fortran Software. NASA Contract Number NAS 915800.

Asrar, G., Fuchs, M., Kanemasu, E. T., \& Hatfield, J. H. (1984). Estimating absorbed photosynthetic radiation and leaf area index from spectral reflectance in wheat. Agronomy Journal, 76, 300-306.

Asrar, G., Myneni, R. B., \& Choudhury, B. J. (1992). Spatial heterogeneity in vegetation canopies and remote sensing of absorbed photosynthetically active radiation: a modeling study. Remote Sensing of Environment, 41, 85-103.

Baret, F., \& Guyot, G. (1991). Potential and limits of vegetation indices for LAI and APAR assessment. Remote Sensing of Environment, 35, 161-173.

Bartlett, D. S., Whiting, G. J., \& Hartmann, J. M. (1990). Use of vegetation indices to estimate intercepted solar radiation and net carbon dioxide exchange of a grass canopy. Remote Sensing of Environment, 30, 115-128.

Burba, G. (2005). Water and energy fluxes in native tallgrass prairie and cultivated wheat ecosystems. (Ph.D. dissertation), 87, Lincoln, US: University of Nebraska-Lincoln.

Buschmann, C., \& Nagel, E. (1993). In vivo spectroscopy and internal optics of leaves as basis for remote sensing of vegetation. International Journal of Remote Sensing, $14,711-722$

Choudhury, B. J. (1987). Relationships between vegetation indices, radiation absorption, and net photosynthesis evaluated by a sensitivity analysis. Remote Sensing of Environment, 22, 209-233.

Ciganda, V. S., Gitelson, A. A., \& Scheper, J. (2012). How deep does a remote sensor sense? Expression of chlorophyll content in a maize canopy. Remote Sensing of Environment, $126,240-247$

Ciganda, V., Gitelson, A. A., \& Schepers, J. (2008). Vertical profile and temporal variation of chlorophyll in maize canopy: Quantitative "crop vigor" indicator by means of reflectance-based techniques. Agronomy Journal, 100, 1409-1417, http://dx.doi.org/ 10.2134/agronj2007.0322.

Darvishzadeh, R., Skidmore, A., Schlerf, M., \& Atzberger, C. (2008). Inversion of a radiative transfer model for estimating vegetation LAI and chlorophyll in a heterogeneous grassland. Remote Sensing of Environment, 112, 2592-2604.

Daughtry, C. S. T. (1988). Estimating absorbed radiation and phytomass from multispectral reflectance of corn and soybean. Proceedings of IGARSS 1988 Symposium, Edinburgh, Scotland, 13-16 Sept. 1988, 821-824. Neuilly, France: Eur. Space Agency.

Daughtry, C. S. T. Gallo, K. P. \& Bauer, M. E. (1983). Spectral estimates of solar radiation intercepted by corn canopies. Agronomy Journal, 75, 527-531.

Fensholt, R., Sandholt, I., \& Rasmussen, M. S. (2004). Evaluation of MODIS LAI, fAPAR and the relation between FAPAR and NDVI in a semi-arid environment using in situ measurements. Remote Sensing of Environment, 91, 490-507.

Gallo, K. P., Daughtry, C. S. T., \& Bauer, M. E. (1985). Spectral estimation of absorbed photosynthetically active radiation in corn canopies. Remote Sensing of Environment 17, 221-232.

Garbulsky, M. F., Penuelas, J., Gamon, J., Inoue, Y., \& Filella, L. (2011). The photochemical reflectance index (PRI) and the remote sensing of leaf, canopy and ecosystem radiation use efficiencies: A review and meta-analysis. Remote Sensing of Environment, 115(2), 281-297.

Gitelson, A. A. (2004). Wide dynamic range vegetation index for remote quantification of crop biophysical characteristics. Journal of Plant Physiology, 161, 165-173.

Gitelson, A. A. (2011). Non-destructive estimation of foliar pigment (chlorophylls, carotenoids and anthocyanins) contents: Espousing a semi-analytical three-band model. In P.S. Thenkabail, J. G. Lyon, \& A. Huete (Eds.), Chapter 6 in hyperspectral remote sensing of vegetation (pp. 141-165). : Taylor and Francis.

Gitelson, A. A., Gritz, U., \& Merzlyak, M. N. (2003). Relationships between leaf chlorophyll content and spectral reflectance and algorithms for non-destructive chlorophyll assessment in higher plant leaves. Journal of Plant Physiology, 160(3), 271-282.

Gitelson, A. A., Keydan, G. P., \& Merzlyak, M. N. (2006). Three-band model for noninvasive estimation of chlorophyll, carotenoids, and anthocyanin contents in higher plan leaves. Geophysical Research Letters, 33, L11402, http://dx.doi.org/10.1029/ 2006 GL026457.

Gitelson, A., \& Merzlyak, M. (1994). Quantitative estimation of chlorophyll-a using reflectance spectra: experiments with autumn chestnut and maple leaves. Journal of Photochemistry and Photobiology B: Biology, 22, 247-252.

Gitelson, A. A., Viña, A., Arkebauer, T. J., Rundquist, D. C., Keydan, G., \& Leavitt, B. (2003) Remote estimation of leaf area index and green leaf biomass in maize canopies. Geophysical Research Letters, 30(5), 1248, http://dx.doi.org/10.1029/2002GL016450 2003.

Gitelson, A. A., Viña, A., Rundquist, D. C., Ciganda, V., \& Arkebauer, T. J. (2005). Remote estimation of canopy chlorophyll content in crops. Geophysical Research Letters, 32 L08403, http://dx.doi.org/10.1029/2005GL022688.

Gitelson, A. A., Viña, A., Verma, S. B., Rundquist, D. C., Arkebauer, T. J., Keydan, G., et al. (2006). Relationship between gross primary production and chlorophyl content in crops: Implications for the synoptic monitoring of vegetation productivity. Journal of Geophysical Research, 111, D08S11, http://dx.doi.org/10.1029/ 2005JD006017.

Goward, S. N., \& Huemmrich, K. F. (1992). Vegetation canopy PAR absorptance and the normalized difference vegetation index: An assessment using the SAIL model. Remote Sensing of Environment, 39, 119-140.
Guillevic, P., \& Gastellu-Etchegorry, J. P. (1999). Modeling BRF and radiative regime of tropical and boreal forests - PART II: PAR regime. Remote Sensing of Environment, $68,317-340$

Guindin-Garcia, N., Gitelson, A. A., Arkebauer, T. J., Shanahan, J., \& Weiss, A. (2012). An evaluation of MODIS 8 and 16 day composite products for monitoring maize green leaf area index. Agricultural and Forest Meteorology, 161, 15-25.

Hall, F. G., Huemmrich, K. F., Goetz, S. J., Sellers, P. J., \& Nickerson, J. E. (1992). Satellite remote sensing of surface energy balance: Success, failures, and unresolved issues in FIFE. Journal of Geophysical Research, 97, 19061-19089.

Hanan, N.P., Burba, G., Verma, S. B., Berry, J. A., Suyker, A., \& Walter-Shea, E. A. (2002). Inversion of net ecosystem $\mathrm{CO} 2$ flux measurements for estimation of canopy PAR absorption. Global Change Biology, 8, 563-574.

Hatfield, J. L., Asrar, G., \& Kanemasu, E. T. (1984). Intercepted photosynthetically active radiation estimated by spectral reflectance. Remote Sensing of Environment, $14,65-75$

Huemmrich, K. F. (1995). An analysis of remote sensing of the fraction of absorbed photosynthetically active radiation in forest canopies. (Ph.D. dissertation), 206, College Park, US: The University of Maryland.

Huemmrich, K. F. (2013). Simulations of seasonal and latitudinal variations in leaf inclination angle distribution: Implications for remote sensing. Advances in Remote Sensing, 2, 93-101.

Huemmrich, K. F., Privette, J. L., Mukelabai, M., Myneni, R. B., \& Knyazikhin, Y. (2005). Time-series validation of MODIS land biophysical products in a Kalahari woodland, Africa. International Journal of Remote Sensing, 2005(26), 4381-4398.

Koetz, B., Baret, F., Polive, H., \& Hill, J. (2005). Use of coupled canopy structure dynamic and radiative transfer models to estimate biophysical canopy characteristics. Remote Sensing of Environment, 95, 115-124.

Merzlyak, M., \& Gitelson, A. (1995). Why and what for the leaves are yellow in autumn? On the interpretation of optical spectra of senescing leaves (Acer platanoides L.). Journal of Plant Physiology, 145(3), 315-320.

Minasny, B., \& McBratney, A.B. (2003). FuzME, Version 3.0 Australian Centre for Precision Agriculture. Sydney: The University of Sydney (http://www.usyd.edu.au/su/agric/acpa).

Monteith, J. L. (1972). Solar radiation and productivity in tropical ecosystems. Journal of Applied Ecology, 9, 747-766.

Myneni, R. B., Asrar, G., Tanre, D., \& Choudhury, B. J. (1992). Remote sensing of solar radiation absorbed and reflected by vegetated land surfaces. IEEE Transactions on Geoscience and Remote Sensing, GE-30, 302-314

Myneni, R. B., Hoffman, S., Knyazikhin, Y., Privette, J. L., Glassy, J., Tian, Y., et al. (2002). Global products of vegetation leaf area and absorbed PAR from year one of MODIS data. Remote Sensing of Environment, 83, 214-231.

Myneni, R. B., Nemani, R. R., \& Running, S. W. (1997). Estimation of global leaf area index and absorbed PAR using radiative transfer model. IEEE Transactions on Geoscience and Remote Sensing, 35, 1380-1393.

Myneni, R. B., \& Williams, D. L. (1994). On the relationship between FAPAR and NDVI. Remote Sensing of Environment, 49, 200-211.

Nakaji, T., Ide, R., Oguma, H., Saigusa, N., \& Fujinuma, Y. (2007). Utility of spectral vegetation index for estimation of gross $\mathrm{CO} 2$ flux under varied sky conditions. Remote Sensing of Environment, 109, 274-284.

Peterson, D. L., \& Running, S. W. (1989). Applications in forest science and management. In G. Asrar (Ed.), Theory and applications of optical remote sensing (pp. 441). New York: John Wiley.

Prince, S. D. (1991). A model of regional primary production for use with course resolution satellite data. International Journal of Remote Sensing, 12, $1313-1330$

Ruimy, A., Saugier, B., \& Dedieu, G. (1994). Methodology for the estimation of terrestrial net primary production from remotely sensed data. Journal of Geophysical Research, 99, 5263-5283.

Rundquist, D., Perk, R., Leavitt, B., Keydan, G., \& Gitelson, A. (2004). Collecting spectral data over cropland vegetation using machine-positioning versus hand-positioning of the sensor. Computers and Electronics in Agriculture, 43(2), 173-178.

Sakamoto, T., Gitelson, A. A., \& Arkebauer, J. J. (2013). MODIS-based corn grain yield estimation model incorporating crop phenology information. Remote Sensing of Environment, 131, 215-231.

Sakamoto, T., Gitelson, A. A., Wardlow, B.D., Verma, S. B., \& Suyker, A. E. (2011). Estimating daily gross primary production of maize based only on MODIS WDRVI and shortwave radiation data. Remote Sensing of Environment, 115, 3091-3101, http://dx.doi.org/10. 1016/j.rse.2011.06.015.

Sakamoto, T., Wardlow, B.D., Gitelson, A. A., Verma, S. B., Suyker, A. E., \& Arkebauer, T. J. (2010). A two-step filtering approach for detecting maize and soybean phenology with time-series MODIS data. Remote Sensing of Environment, 114, 2146-2159.

Sellers, P. (1985). Canopy reflectance, photosynthesis and transpiration. International Journal of Remote Sensing, 8, 1335-1372.

Sims, D. A., Hongyan, L., Hastings, S., Oechel, W. C., Rahman, A. F., \& Gamon, J. A. (2006). Parallel adjustments in vegetation greenness and ecosystem $\mathrm{CO} 2$ exchange in response to drought in a Southern California chaparral ecosystem. Remote Sensing of Environment, 103, 289-303.

Suyker, A. E., \& Verma, S. B. (2010). Coupling of carbon dioxide and water vapor exchanges of irrigated and rainfed maize-soybean cropping systems and water productivity. Agricultural and Forest Meteorology, 150, 553-563.

Tucker, C. J. (1979). Red and photographic infrared linear combinations for monitoring vegetation. Remote Sensing of Environment, 8, 127-150.

Verhoef, W. (1984). Light scattering by leaf layers with application to canopy reflectance modeling: The SAIL model. Remote Sensing of Environment, 16, $125-141$. 
Verma, S. B., Dobermann, A., Cassman, K. G., Walters, D. T., Johannes, M., Knops, J. M., et al. (2005). Annual carbon dioxide exchange in irrigated and rainfed maize-based agroecosystems. Agricultural and Forest Meteorology, 131, 77-96.

Viña, A., \& Gitelson, A. A. (2005). New developments in the remote estimation of the fraction of absorbed photosynthetically active radiation in crops. Geophysical Research Letters, 32, L17403, http://dx.doi.org/10.1029/2005GL023647.

Viña, A., Gitelson, A. A., Nguy-Robertson, A. L., \& Peng, Y. (2011). Comparison of different vegetation indices for the remote assessment of green leaf area index of crops.
Remote Sensing of Environment, 115, 3468-3478, http://dx.doi.org/10.1016/j.rse. 2011.08.010.

Viña, A., Gitelson, A. A., Rundquist, D. C., Keydan, G., Leavitt, B., \& Schepers, J. (2004) Monitoring maize (Zea mays L.) phenology with remote sensing. Agronomy Journal, 96, 1139-1147.

Wu, C., Niua, Z., \& Gaoa, S. (2012). The potential of the satellite derived green chlorophyll index for estimating midday light use efficiency in maize, coniferous forest and grassland. Ecological Indicators, 14, 66-73. 